\title{
Air Pollution, Stress, and Allostatic Load: Linking Systemic and Central Nervous System Impacts
}

\author{
Errol M. Thomson* \\ Environmental Health Science and Research Bureau, Healthy Environments and Consumer Safety Branch, \\ Health Canada, Ottawa, ON, Canada
}

Accepted 23 March 2019

\begin{abstract}
Air pollution is a risk factor for cardiovascular and respiratory morbidity and mortality. A growing literature also links exposure to diverse air pollutants (e.g., nanoparticles, particulate matter, ozone, traffic-related air pollution) with brain health, including increased incidence of neurological and psychiatric disorders such as cognitive decline, dementia (including Alzheimer's disease), anxiety, depression, and suicide. A critical gap in our understanding of adverse impacts of pollutants on the central nervous system (CNS) is the early initiating events triggered by pollutant inhalation that contribute to disease progression. Recent experimental evidence has shown that particulate matter and ozone, two common pollutants with differing characteristics and reactivity, can activate the hypothalamic-pituitary-adrenal (HPA) axis and release glucocorticoid stress hormones (cortisol in humans, corticosterone in rodents) as part of a neuroendocrine stress response. The brain is highly sensitive to stress: stress hormones affect cognition and mental health, and chronic stress can produce profound biochemical and structural changes in the brain. Chronic activation and/or dysfunction of the HPA axis also increases the burden on physiological stress response systems, conceptualized as allostatic load, and is a common pathway implicated in many diseases. The present paper provides an overview of how systemic stress-dependent biological responses common to particulate matter and ozone may provide insight into early CNS effects of pollutants, including links with oxidative, inflammatory, and metabolic processes. Evidence of pollutant effect modification by non-chemical stressors (e.g., socioeconomic position, psychosocial, noise), age (prenatal to elderly), and sex will also be reviewed in the context of susceptibility across the lifespan.
\end{abstract}

Keywords: Air pollution, brain, cognition, dementia, depression, hypothalamic-pituitary-adrenal (HPA) axis, mental health, ozone, particulate matter

\section{INTRODUCTION}

Studies conducted around the world have consistently shown that variation in air pollution levels is associated with cardiovascular and respiratory

\footnotetext{
*Correspondence to: Errol M. Thomson, Inhalation Toxicology Laboratory, Hazard Identification Division, Environmental Health Science and Research Bureau, Health Canada, 0802B Tunney's Pasture, Ottawa, ON K1A 0K9, Canada. Tel.: +1 613941 7151; E-mail: errol.thomson@canada.ca.
}

morbidity and mortality $[1,2]$. Recently, health conditions associated with exposure to common air pollutants have broadened to include impacts on the brain such as anxiety, depression, cognitive deficits, and dementia. The societal implications are significant: neurological and mental health disorders globally represent the largest contributor to years lived with disability, and with an aging population the proportion of affected individuals is growing [3, 4]. Given the ubiquitous exposure of the population to 
air pollution, and the prevalence of psychiatric and neurological diseases, even small increases in relative risk translate to a substantial public health burden.

Despite compelling evidence that the brain is a target of air pollutants, and that inflammation and oxidative stress are common features of pollutantinduced disease processes, mechanisms linking pollutant inhalation to effects in the brain remain poorly understood [5-7]. In particular, we lack insight into the early initiating events triggered by exposure to air pollutants that lead to disease processes in the brain. Elucidating mechanisms that directly link exposure to air pollutants with effects in the brain is a critical step toward addressing several key knowledge gaps. These include whether common or distinct processes underlie the relationship between exposure to air pollutants and diverse central nervous system (CNS) disorders (e.g., cognitive decline, dementia, depression), each of which has both common and distinct features and etiology. Understanding whether or not biological effects are specific to individual pollutants has implications for risk management and the targeting of key actors for regulatory action. Furthermore, with increased understanding of underlying mechanisms comes knowledge needed to identify those factors that contribute to susceptibility.

Recent work has shown that among the early biological responses triggered by exposure to air pollutants is a stress response that includes activation of the hypothalamic-pituitary-adrenal (HPA) axis and release of stress hormones. Dysregulation of the HPA axis is a feature of many disease processes common to both chronic stress and long-term exposure to air pollution, including cardiovascular disease, metabolic diseases such as type 2 diabetes, cognitive disorders, and depression [8]. Chronic stress and dysregulation of stress response systems have been proposed to contribute to both neurodegenerative diseases such as Alzheimer's disease and to psychiatric disorders such as depression [9], making this mechanism an attractive target for investigation of mediators underlying CNS effects of air pollutants. The present paper examines how HPA axis dysfunction may contribute to CNS impacts associated with exposure to air pollutants. Effects of two common pollutants, ambient particulate matter and ozone, will be examined in relation to their differing physicochemical properties and mode of action. Recent evidence of stress axis activation by these pollutants will be summarized, and both the direct effects of stress axis activation on the CNS as well as indirect (systemic) consequences relevant to brain health will be reviewed. The poten- tial contributions to brain disorders of converging biological pathways and their impact on cumulative physiological dysregulation, or allostatic load, will be discussed. Finally, the relevance of the stress response system to susceptibility will be examined by reviewing recent evidence of sex-dependent effect modification involving prior or co-exposure to nonchemical stressors across the life course.

\section{PARTICULATE MATTER AND OZONE: DISTINCT PROPERTIES, OVERLAPPING HEALTH IMPACTS}

Particulate matter (e.g., PM2.5 and PM10, particles with an aerodynamic diameter less than 2.5 and $10 \mu \mathrm{m}$, respectively) and ozone are currently considered to be the most important criteria pollutants with respect to morbidity and mortality. The Global Burden of Disease project attributed 4.2 million deaths and 103 million disability-adjusted life-years (essentially a measure of years of healthy living lost) to ambient particulate matter, with an additional 254,000 deaths and 4.1 million disability-adjusted life-years attributed to ozone [2]. As global mortality estimates have traditionally considered five specific causes of death (ischemic heart disease, lower respiratory infections, chronic obstructive pulmonary disease, lung cancer, and cerebrovascular disease), evidence of associations between air pollutants and reproductive (e.g., low birth weight), metabolic (e.g., diabetes), and neurological/mental health disorders suggests that the societal impact of air pollutants may actually be greater than currently appreciated. Indeed, recent work incorporating data from cohort studies spanning much of the range of global particulate levels yielded estimates of excess non-accidental deaths attributable to exposure to particulate matter that were significantly higher than previously recognized [10].

Air pollution is a complex mix of particles and gases that varies in relation to local and regional source contributions and atmospheric conditions. Particulate matter is itself a complex mixture that includes a number of toxic constituents such as transition metals, organics, sulfur, and black carbon derived from anthropogenic emissions as well as crustal sources. In vitro studies using cultured lung cell models have shown that particles compared on an equal mass basis can vary significantly in their cytotoxic and inflammatory potential in relation to spatial and temporal variations in contributions from traffic, industrial, and other urban sources [11-13]. Although 
challenging to study at the population level, there is evidence that such differences in composition contribute to spatial variation in health impacts $[14,15]$. However, while characteristics such as surface area, transition metals, and most recently oxidative potential have, among others, been identified as potential drivers for health effects of particulate matter [16], to date, mass concentration of a given particle size fraction continues to be the key metric used for regulatory action.

Even less is known about drivers of CNS effects. Because of their size and properties, considerable experimental work has focused on potential translocation of nanoparticles to the systemic circulation and brain, and on pathological effects produced in the brain following chronic exposure to particles, resulting in important findings supporting the plausibility of pollutant effects on brain health [7, 17-19]. Depending on size and chemical composition, particulate matter or soluble constituents may translocate from the lungs to the systemic circulation, or migrate via olfactory transport, and directly interact with extrapulmonary cells and tissues including the brain $[18,20]$. However, pollutants need not physically reach the brain, nor must there be chronic exposure, to provoke effects. A number of experimental studies (e.g., [21-24]) have identified structural, functional, biochemical, and transcriptional alterations in the brain following both acute and repeated exposure to the highly-reactive gas ozone. Because of its reactivity, ozone is consumed within the lungs through reactions with lipids, proteins, and antioxidants present in the airway surface lining, and extrapulmonary ozone toxicity is thought to be mediated by secondary reactive products and other biological mediators released into the systemic circulation [25, 26]. Particulate matter, too, may impact the brain through indirect processes, such as through effects secondary to peripheral oxidative stress and inflammation, or to stimulation of pulmonary neuronal afferents, as has been proposed to explain cardiovascular impacts $[1,7]$.

Despite their differing properties and potential routes of exposure, both particulate matter and ozone have been associated with a variety of CNS impacts. These include impaired cognitive performance [27-29], dementia [30, 31], anxiety and depression [32-35], and suicide [36-38]. It should be noted that there is considerable variability in the epidemiologic literature; a more comprehensive overview of associations between particulate matter or ozone and neurological/mental health outcomes is provided in several recent reviews $[5,6,20,39$, 40]. In experimental models, repeated exposure to air pollutants including ambient particulate matter and ozone has been shown to increase oxidative stress and cytokine production in the brain, with evidence also of microglial activation and impacts on neurotransmitters, neuronal morphology, markers of neurodegenerative disease, altered cognition, and depressive-like behaviors (e.g., [21, 24, 41-43]). Collectively, epidemiological and toxicological studies have found that both particulate and gaseous pollutants, despite distinct physicochemical characteristics and biological reactivity, can impact brain health. Notwithstanding advances in our understanding that exposure to ambient pollutants can adversely impact the CNS, a critical knowledge gap remains the initiating mechanism(s) through which exposure to pollutants leads to effects in the brain.

\section{INITIAL EFFECTS OF PARTICULATE MATTER AND OZONE: EVIDENCE OF A COMMON MEDIATOR}

The physicochemical differences between particulate matter and ozone provide a useful contrast to investigate mechanisms underlying extrapulmonary effects of air pollutants. Unlike effects of ambient particles, which could be due to direct effects of the nanosized fraction or soluble constituents on target tissues, or to secondary effects from signaling via the systemic circulation or nervous inputs, extrapulmonary effects of ozone are attributable to secondary mediators. Extrapulmonary effects that are common to both pollutants could therefore provide evidence of a common secondary mediator or mediators, while distinct effects provide insight into pollutant-specific processes.

To investigate systemic impacts of inhaled pollutants, we exploited this contrast by comparing gene expression profiles in rats exposed to particulate matter, ozone, or both pollutants (Fig. 1A) [44]. We measured the expression of a set of genes representing a number of biological pathways in the lungs, heart, liver, kidney, spleen, cerebral hemisphere, and pituitary gland. We reasoned that examination of the pattern of response immediately after a single acute $(4 \mathrm{~h})$ exposure would allow assessment of initial pollutant effects not significantly influenced by subsequent cellular changes that accompany disease progression observed in repeated or chronic exposure models. Effects of exposure to particulate matter or 

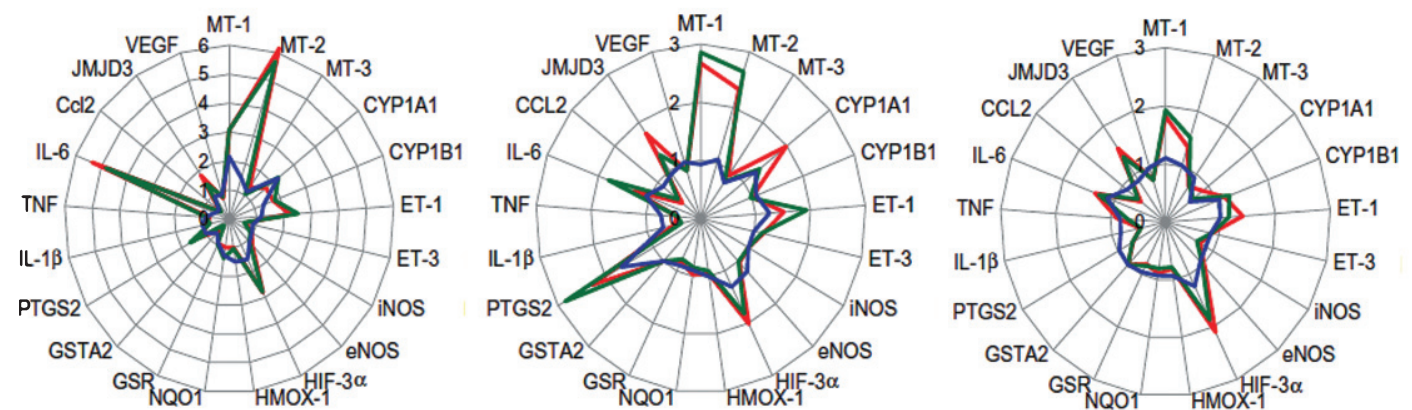

B

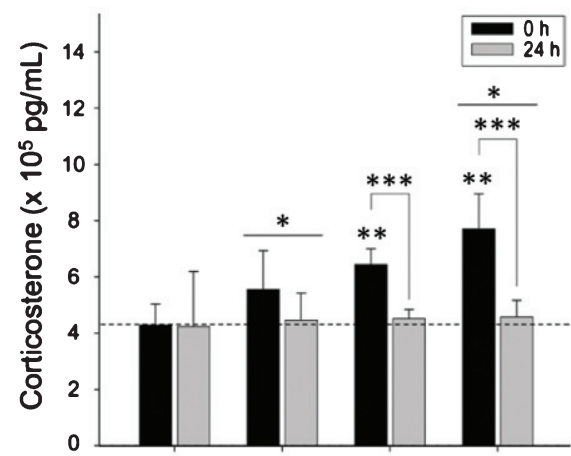

C

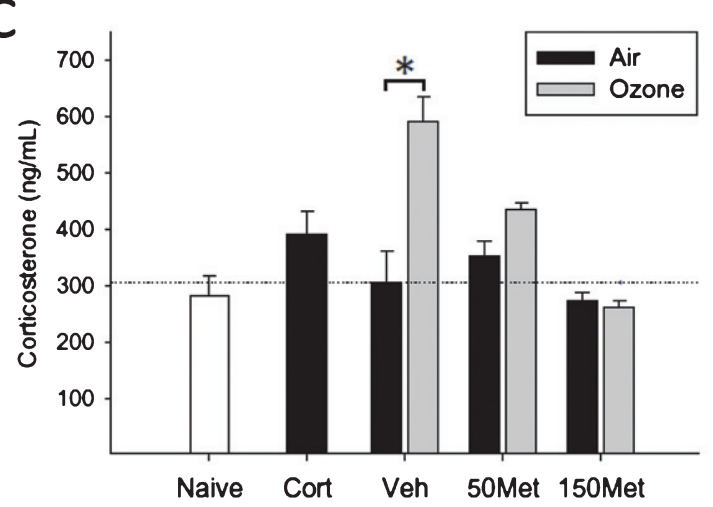

\begin{tabular}{llccc}
$\mathrm{EHC}\left(\mathrm{mg} / \mathrm{m}^{3}\right)$ & 0 & 50 & 0 & 50 \\
\hline Ozone $(\mathrm{ppm})$ & 0 & 0 & 0.8 & 0.8
\end{tabular}
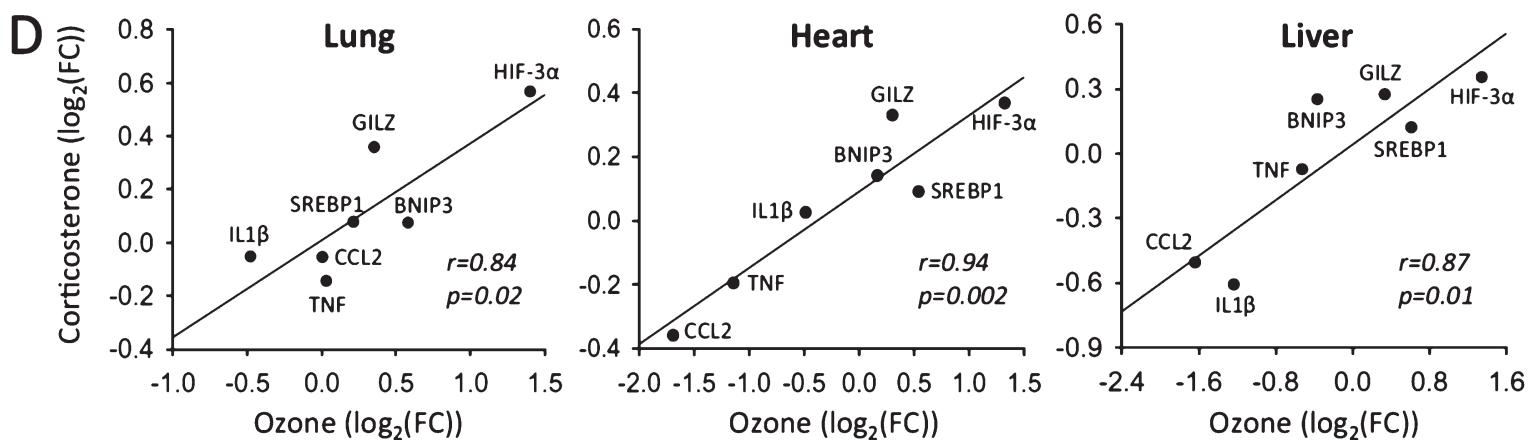

Fig. 1. Systemic effects of particulate matter and ozone include activation of the hypothalamic-pituitary-adrenal (HPA) stress axis. A) Gene expression profiles (fold-change relative to air-exposed controls) were mapped across a variety of tissues in Fischer rats exposed by nose-only exposure for $4 \mathrm{~h}$ to particulate matter (blue), ozone (red), or particulate matter and ozone (green). B) Both particulate matter (EHC) and ozone increase plasma corticosterone $\left({ }^{*}\right.$ significant particle effect; ${ }^{* *}$ significant ozone effect; ${ }^{* * *}$ significant time effect). C) Treatment with the drug metyrapone $(50 \mathrm{mg} / \mathrm{kg}, 150 \mathrm{mg} / \mathrm{kg} \mathrm{Met})$ blocked the ozone-induced increase in corticosterone ( $n=5 /$ group). Naïve, rats not exposed to experimental paradigm; Cort, rats administered exogenous corticosterone and exposed to air. D) Administration of corticosterone (10 mg/kg) reproduced effects of ozone exposure (FC, fold-change). Figures reproduced or adapted from references 44 (A, B) and 54 (C, D).

ozone were observed in every organ, including robust effects in the cerebral hemisphere and pituitary. Remarkably, despite contrasting effects in the lungs (e.g., strong induction of interleukin- 6 by ozone, and of xenobiotic response genes by particles), a subset of genes that included inflammatory, antioxidant, and stress-responsive factors exhibited a similar pattern of response to the pollutants across most organs. The pronounced response observed in the pituitary, coupled with responses common to all tissues assessed, led us to hypothesize endocrine involvement. Subsequent analyses confirmed that both particulate matter and ozone activated the HPA axis and provoked the release of the stress hormones adrenocorticotrophic 
hormone (ACTH) and corticosterone (Fig. 1B) [44].

\section{THE HPA AXIS: AIR POLLUTANTS AS STRESSORS}

Together with the sympathetic nervous system, the HPA axis plays a pivotal role in coordinating the response to stressors. Stressor exposure triggers hypothalamic production of corticotrophin-releasing hormone; this signals the pituitary to synthesize $\mathrm{ACTH}$, which is released into the systemic circulation. Upon reaching the adrenal glands, ACTH stimulates de novo synthesis of glucocorticoids (primarily cortisol in humans, corticosterone in rodents) that are in turn released into circulation. Glucocorticoids act primarily through specific receptors to exert profound effects on a variety of processes that include glucose and lipid metabolism, immune response, and adipocyte differentiation, as well as interacting with other endocrine systems [45]. Depending on the intensity and duration of exposure, glucocorticoids can both stimulate and inhibit immune responses $[46,47]$. Glucocorticoid production is shut down by means of a negative feedback mechanism. Acute activation of the HPA axis is essential for survival, providing the body with the means to respond to acute stressors including mobilizing and replenishing energy reserves and regulating immune responses. However, chronic activation of the HPA axis produces various deleterious consequences: both chronic stress and excess glucocorticoids are associated with increased risk of cardiovascular disease, metabolic dysfunction, depression, and reduced cognitive function [48]. There is a substantial overlap between stress-related diseases and diseases associated with exposure to air pollutants [8].

Recent experimental work has demonstrated that air pollutants can act as stressors and elicit endocrine stress responses. Exposure of rats to concentrated ambient particles, with and without ovalbumininduced allergic disease, activated stress centers in the brain and increased circulating levels of corticosterone [49]. Short-term exposure of rats to ozone and particulate matter altered expression of pituitary endothelin-1 [23], a regulator of pituitary hormone secretion [50]. Ozone exposure activated stress centers in the brain of adult rats, with the pattern of activation suggesting signaling via the vagus nerve [51]. Repeated exposure of seven-week old female Wistar rats to ozone $(0.12 \mathrm{ppm}, 6 \mathrm{~h} /$ day for $15 \mathrm{~d})$ resulted in higher plasma corticosterone that coincided with behavioral changes [52]. Acute exposure to particulate matter or ozone increased plasma levels of the stress hormones ACTH and corticosterone and altered expression across multiple tissues in Fischer rats, confirming that a single exposure to either particulate or gaseous pollutants can activate the HPA axis and produce common (and additive) systemic effects [44]. Short-term exposure to ozone increased epinephrine levels in Brown Norway rats [53], consistent with a response of the sympathetic nervous system as part of the stress response. Blocking the ozone-induced increase of corticosterone using the drug metyrapone increased inflammatory signaling in the lungs and circulation, consistent with immunosuppressive action of glucocorticoids, and prevented effects of ozone on metabolic and inflammatory factor expression in several organs [54]. Effects of ozone were reproduced by administration of corticosterone (Fig. 1C, D), confirming a role for the HPA axis in mediating and modifying local and systemic effects of ozone exposure [54]. More recently, evidence of adrenal stress hormone involvement was further substantiated in a study that showed that administration of adrenergic and glucocorticoid receptor antagonists prior to and concurrent with exposure modified the pulmonary response to ozone [55]. The relevance of these observations to humans was confirmed in a panel study that showed that controlled exposure to $0.2 \mathrm{ppm}$ ozone increased plasma stress hormone levels [56]. Furthermore, reduction of indoor particulate matter levels using a particle filter was associated with a drop in cortisol levels in a randomized doubleblind crossover design study [57]. Collectively, these studies show that exposure to gaseous and particulate pollutants can elicit neuroendocrine stress responses.

\section{DIRECT EFFECTS OF STRESS AXIS DYSREGULATION ON THE BRAIN}

The demonstration that air pollutants can activate the HPA stress axis has important implications with respect to potential direct and indirect effects on the brain (Fig. 2). Effects of stress and stress hormones on the brain have been investigated for decades, leading to insights into impacts of acute and chronic stressors on molecular signaling, neuronal structure, and brain plasticity $[58,59]$. Both acute and chronic stress produce neurochemical and structural changes in the brain that have consequences for neurodevelopmental processes as well as healthy aging [60]. Cortisol 


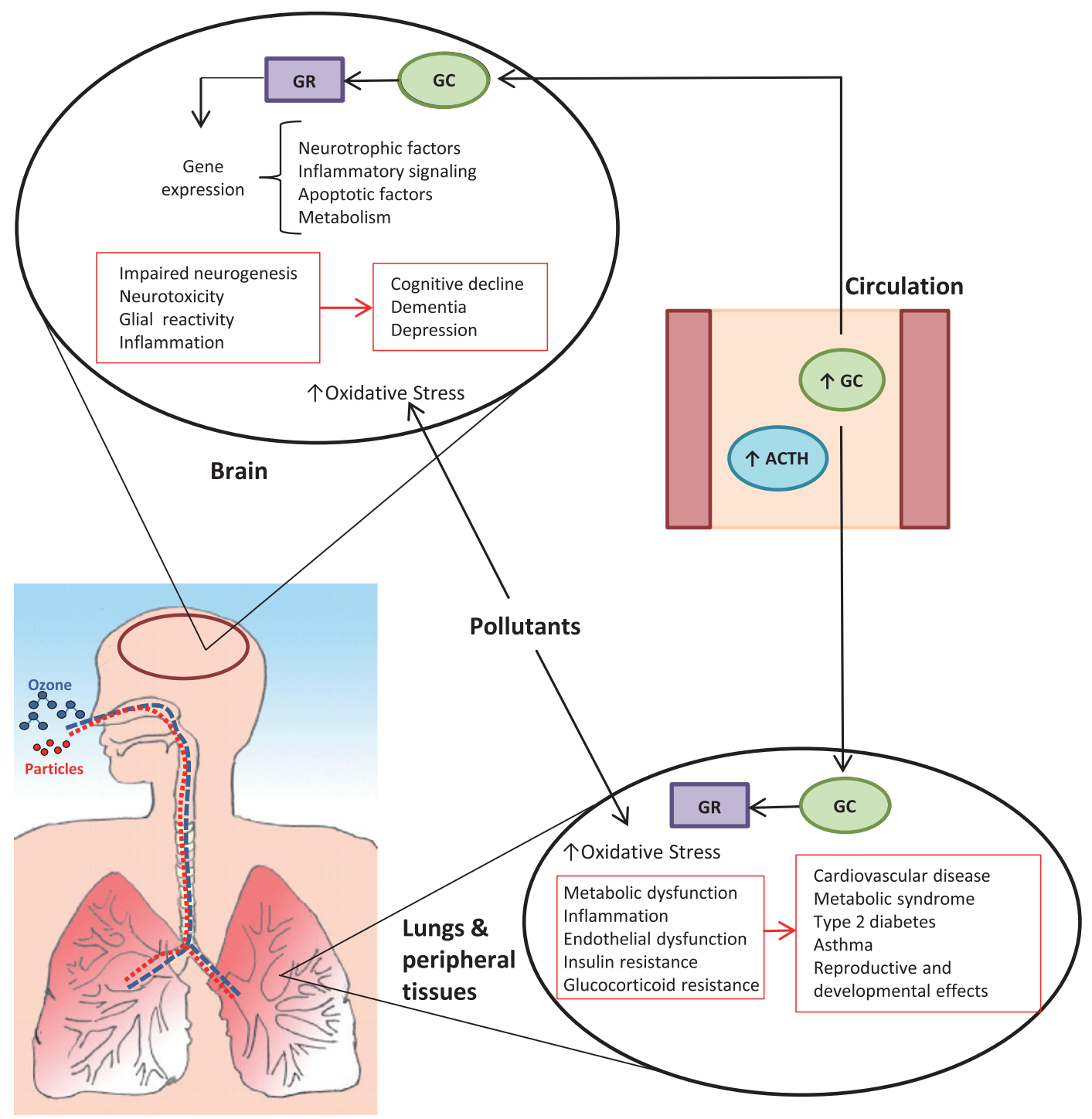

Fig. 2. Proposed direct and systemic impacts of pollutant-induced stress axis activation on the brain. Both particulate matter and ozone trigger a stress response, resulting in pituitary release of adrenocorticotrophic hormone (ACTH), which in turn signals the adrenal glands to increase production of glucocorticoids (GC; primarily cortisol in humans, corticosterone in rodents). Glucocorticoids bind to receptors (GR) to regulate processes that include glucose and lipid homeostasis, immune/inflammatory function, and responses to other hormones. The stress hormone release coincides with and contributes to changes in blood mediators (e.g., cytokines, metabolic factors, reactive products) that have systemic impacts, including effects on the brain, lungs, and peripheral tissues. Chronic activation and dysregulation of the HPA axis is associated with a variety of adverse effects that include neurotoxicity, sensitization to other insults including oxidative stress, and impaired control of inflammatory processes. Collectively, these effects interact with individual susceptibility to contribute to disease processes that manifest systemically and in the brain.

plays a central role in regulating fetal brain development, including the regulation of neurotrophic factors such as serotonin [61]. Stress and elevated glucocorticoid levels are implicated in prevalent brain disorders that include depression and dementia [48, 62-64]. Among older adults, individuals with progressively higher basal cortisol levels over several years were found to have greater memory impairment and lower hippocampal volume than individuals with lower cortisol levels [65]. Interindividual differences in HPA axis reactivity explain the relationship between serotonin transporter gene single nucleotide polymorphisms and susceptibility to depression [66], suggesting that differences in stress response may also be important modifiers of the effect of chronic stressors on mental health. 
The brain is highly sensitive to glucocorticoids. Much of our understanding of the effects of glucocorticoids on the brain were founded upon original studies examining effects in the hippocampus, which were then extended to other regions including the amygdala and prefrontal cortex [58]. Under the glucocorticoid-cascade hypothesis (now called the neurotoxicity hypothesis), effects of cumulative exposure to elevated glucocorticoid levels can lead to hippocampal atrophy [67]. Stress is a strong negative regulator of hippocampal neurogenesis, thought to be a key cause of morphological and functional deficits observed in depression [68]. Because the hippocampus contributes to regulation of the HPA axis, this effect can contribute to HPA axis dysregulation, a feed-forward effect that may eventually impair cognition $[67,69]$.

Both particulate matter and ozone alter the expression of glucocorticoid-regulated genes in the brain of exposed rats ([44] and unpublished observations), consistent with biologically-effective increases in cerebral glucocorticoid concentrations following pollutant exposure. While it remains to be determined to what extent stress axis dysfunction is implicated in adverse CNS impacts of air pollutants, there is considerable experimental evidence to support a direct causal role for glucocorticoids and HPA axis dysfunction in brain pathologies. Repeated exposure of rats to exogenous corticosterone impaired memory and accelerated hippocampal neuronal loss and glial reactivity, while adrenalectomy alleviated these characteristics of brain aging [70, 71]. Glucocorticoid hypersecretion is associated with reduced hippocampal volume and memory impairments in rats [72], showing that individual differences in glucocorticoid levels may be relevant to brain health. Depending on dose, duration, and brain region, glucocorticoids appear to differentially impact proliferation of oligodendrocyte progenitors [73, 74], and microstructural changes indicative of loss of integrity and demyelination have been observed in the white matter of patients with Cushing Syndrome [75]. In addition to their well-established anti-inflammatory role, glucocorticoids can exert early permissive immunostimulative effects in the periphery, as well as proinflammatory effects during the immune response to injury in the CNS, that appear to depend upon level, timing, and duration of exposure [47]. Chronic administration of glucocorticoids has been shown to increase amyloid- $\beta$ prevalence in the brain of aged macaques, possibly by impairing expression of insulin-degrading enzyme, a candidate protease for clearance of amyloid- $\beta$ peptides [76]. 11 $\beta$-hydroxysteroid dehydrogenase $1-/$ mice, which lack a key enzyme responsible for tissuespecific conversion of glucocorticoid precursors to the active form, are protected from the cognitive decline that affects aged wild-type mice [77], emphasizing the importance of tissue glucocorticoid levels in mediating effects. Repeated exposure to corticosterone is used as a model of depression [78], and subchronic treatment with a glucocorticoid receptor inhibitor prevented the cognitive decline observed in a transgenic mouse model of Alzheimer's disease [79]. Collectively, these and other studies establish a causal link between dysregulated glucocorticoids and impacts on cognition, neurodegeneration, and depression.

\section{STRESS-DEPENDENT SYSTEMIC INVOLVEMENT IN CNS DYSFUNCTION}

Systemic effects of pollutant exposure, like systemic effects of chronic stress, may also contribute to impacts on the brain. Major systems and factors that contribute to an integrated stress response include the sympathetic nervous system, immune system (including actions of inflammatory cytokines), and metabolic factors. Chronic elevation of glucocorticoids, as seen in Cushing Syndrome, is associated with hyperglycemia, impaired immune function, hypertension, obesity, and depression [45, 80]. The hypercortilism and inflammation seen in stress-related diseases such as cardiovascular disease, metabolic syndrome, and depression have been proposed to result from glucocorticoid resistance [80]. Co-morbidity of metabolic and neurological/neurobehavioral disorders is well-established, and is thought to relate at least in part to common underlying dysfunction of the HPA axis [48, 81-83].

The brain is highly sensitive to metabolic disturbance, oxidative stress, and inflammatory stimuli. Glucocorticoids exert well-known impacts on metabolic systems, including antagonizing insulin signaling and regulating glucose and fatty acid homeostasis [84, 85]. Insulin signaling is implicated in neuronal and cognitive function [86], and insulin resistance is associated with increased risk for Alzheimer's disease [87]. Insulin-degrading enzyme is implicated in the regulation of amyloid- $\beta$ levels, with knockout mice exhibiting increased cerebral accumulation of amyloid- $\beta$, hyperinsulinemia, and glucose intolerance [88]. Reduced glucose tolerance 
has been associated with poor memory performance and hippocampal atrophy [89], and insulin resistance was associated with reduced cerebral glucose uptake and increased risk of Alzheimer's disease [90]. Experimental models have shown that repeated exposure to corticosterone produces a model of depression [78], and when combined with a high-fat diet produces a model of type II diabetes [91], implicating glucocorticoids in metabolic and neurobehavioral disorders.

There is abundant epidemiological and experimental data to show that exposure to air pollutants can lead to dysregulation of metabolic and inflammatory processes [92]. For example, mice exposed chronically to concentrated ambient particles and a high fat diet developed insulin resistance, systemic inflammation, and increased visceral fat deposition [93]. Acute exposure to ozone produced glucose intolerance in Brown Norway rats [53], and in mice produced insulin resistance partially reversed by antioxidant treatment [94]. There is currently limited data to show to what extent the stress axis is involved in such effects, particularly in chronic exposure models, as data to date come from short-term exposure studies. Pharmacological intervention with metyrapone, a drug that blocks corticosterone synthesis, prevented a subset of acute ozone-dependent metabolic effects in male Fischer rats and enhanced the release of some cytokines into the circulation after ozone exposure [54]. Adrenalectomy alleviated acute ozone-induced decreases in glucose tolerance in Wistar-Kyoto rats [95], consistent with the involvement of adrenal hormones. Ozone-dependent changes in the response of metabolic and endocrine factors to glucose challenge were reproduced by administration of corticosterone, supporting a role for glucocorticoids in mediating pollutant effects [96]. Given the co-morbidity of metabolic and neurological and neurobehavioral disorders and the sensitivity of the brain to metabolic and inflammatory stimuli, such changes may have relevance to impacts of pollutants on the brain.

\section{CONVERGING PATHWAYS: OXIDATIVE STRESS, INFLAMMATION, AND THE NEUROENDOCRINE STRESS RESPONSE}

The diverse health impacts now associated with exposure to air pollution suggest involvement of a number of processes that manifest according to the specific makeup of the pollutant mix and interindividual differences in susceptibility. Stress axis dysfunction is unlikely to be the only factor involved. Oxidative stress and inflammation have long been considered important features of disease processes initiated by pollutants, including effects in the brain, where lipid peroxidation, microglial activation, and increased levels of inflammatory cytokines have been observed in experimental models following both acute and chronic exposure [97, 98]. These, along with impacts on neurotransmitter systems and changes of neuronal structure and function, have been proposed as prominent mechanisms underlying CNS impacts of pollutant exposure [6, 7].

Recent human data support involvement of oxidative stress and inflammatory pathways in a variety of pollutant effects relevant to brain health. For example, associations between prenatal exposure to ambient pollutants and impaired cognitive development were strongest in the offspring of mothers who reported low fruit and vegetable consumption, important sources of antioxidants [99]. Mitochondrial DNA copy number, which increases in response to environmental demands and oxidative damage, has been associated with exposure to pollutants in utero and in later life [100, 101]. Although the physiological consequences are not entirely clear, mitochondrial damage is associated with a variety of disorders including neurodegenerative diseases [102]. Black carbon exposure averaged over a year was associated with reduced cognitive function, with stronger effects observed in individuals with longer leukocyte telomeres, a characteristic associated with the capacity to mount a stronger systemic inflammatory response [103]. In addition to this potential role as an effect modifier, telomere length may also reflect oxidative and inflammatory stresses linked to exposures, with long-term exposures to a range of occupational and environmental toxicants generally associated with shorter leukocyte telomere length [104]. This emerging literature supports a role for air pollution in contributing to fetal programming and to accelerated aging, at least in part through cumulative effects of oxidative and inflammatory stresses.

Basal glucocorticoid levels and pollutantdependent regulation of the HPA axis may contribute to such effects. Rodent studies have shown that the hippocampus, in addition to being highly sensitive to glucocorticoids, appears also to be particularly sensitive to the oxidative stress caused by ozone exposure [105, 106], and exhibits inflammatory signaling, impaired neurogenesis, and altered neuronal morphology following long-term exposure to concentrated ambient particles or traffic-related air 
pollutants [42, 107, 108]. In addition to exerting neurotoxic effects and impairing neurogenesis, chronic stress and elevated glucocorticoids can prime microglial proinflammatory responses to subsequent insults $[109,110]$. Like oxidative stress, psychological stress and elevated glucocorticoid levels are associated with accelerated telomere shortening [111-113]. Glucocorticoids also regulate mitochondrial function, correlating with neuroprotection at low levels and neurotoxicity at high levels [114]. As air pollutants may act through diverse pathways, such combined effects may render specific brain structures vulnerable to air pollutants, depending on individual host susceptibility and exposure to other stressors.

\section{ALLOSTATIC LOAD: CUMULATIVE PHYSIOLOGICAL DYSFUNCTION FROM CHRONIC STRESSOR EXPOSURE}

Adaptation to stressors requires an integrated response that is essential for survival, but is not without cost. Diseases associated with chronic stress, as with chronic exposure to air pollution, are characterized by common underlying processes that include dysregulation of endocrine, inflammatory, and metabolic systems. If air pollutants act as stressors through impacts on the HPA axis, considering the combined and cumulative effects of multiple stressors and innate differences in stress reactivity may be important to understand conditions that contribute to susceptibility. Key concepts that may help to explain how the cumulative burden imposed by exposure to stressors increases the likelihood of morbidity and mortality include allostasis, which describes the process by which the body responds to exposure to stressors, and allostatic load, which describes the wear and tear on the body as it responds to stressors [115]. In essence, allostatic load represents the physiological consequences of prolonged exposure to stressors interacting with individual host sensitivity. While stress response systems have evolved to respond to acute stressors by providing a survival advantage, chronic activation imposes a burden that may alter the capacity to respond to new challenges, increasing vulnerability to new stressors and contributing to disease processes (Fig. 3). This, coupled with interindividual variability in stress responses, may explain why small changes in the levels of a stressor that is tolerated in some individuals can, in others, produce an adverse effect.

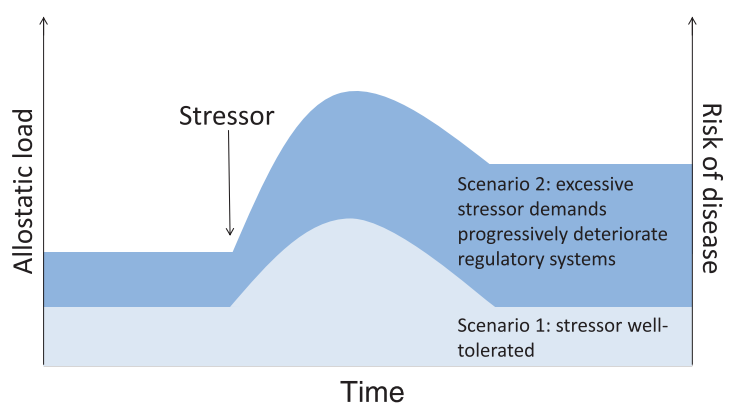

Fig. 3. Allostatic load scenarios. Both intrinsic (e.g., stress reactivity, resilience, existing disease states) and extrinsic (e.g., prior and concurrent exposure to other psychosocial, physical, or chemical stressors) factors will interact to determine to what extent stressor exposure contributes to physiological dysfunction, or allostatic load, and increases the risk of disease.

Efforts to operationalize the allostatic load concept using composite indices that incorporate a set of biological measures covering physiological processes dysregulated by chronic stress (e.g., cortisol, epinephrine, cholesterol, glycated hemoglobin, blood pressure, waist-to-hip ratio, C-reactive protein) have shown its utility in predicting mortality, as well as physical and cognitive decline [116]. For example, higher baseline allostatic load scores in men and women aged 70-79 were associated with a steeper decline in cognitive function over a seven year followup period [117]. In a large cross-sectional study, higher allostatic load scores were associated with poorer working memory in adults aged 20-59 [118]. Allostatic load during childhood was associated with poorer working memory in young adults [119]. Such relationships may have relevance in interpreting associations between pollutants and health outcomes. For example, long-term exposure to air pollutants was associated with impaired performance on mathematical and verbal tests, with effects of pollutant exposure on verbal skills most evident with increasing age and lower education [27].

The concept of allostatic load provides insight into social gradients in health that relate to exposure to chronic stressors, including air pollution. It has been recognized for some time that socioeconomic position, in addition to being a potential confounder of associations between exposure to air pollutants and health outcomes, may also be an effect modifier. O'Neill and colleagues identified three mechanisms that may explain the increased adverse effects on health associated with air pollution among individuals of lower socioeconomic position, namely: 1) susceptibility directly related to socioeconomic 
position, such as through higher levels of psychosocial stress, limited access to health care, or increased likelihood of living in lower quality housing and associated greater exposure to stressors such as noise, crowding, violence, allergens, and other pollutants; 2) higher prevalence of health conditions and behaviors that increase susceptibility such as diabetes and smoking; and 3) more frequent or more intense exposures to air pollution [120]. Stress may be common to all three. If air pollution acts as a chronic stressor, contributing to allostatic load and accelerating the progression of stress-associated diseases, gradients in exposure to stressors and individual differences in sensitivity and behavior may act as important modifiers of health impacts. Factors associated with resilience may also modify the response to pollutants, as suggested by evidence that exposure to natural environments (e.g., green and blue spaces) is associated with protective effects, including improvements in allostatic load measures, cardiovascular and mental health outcomes, and risk of cause-specific mortality [121-123].

\section{VULNERABILITY: INTERACTIONS WITH SEX, AGE, AND NON-CHEMICAL STRESSORS}

Differences in the magnitude and nature of effects of air pollutants on health are thought to depend both on subject-specific traits (such as age, sex, existing disease, genetic variation, behaviors) and contextual characteristics (such as socioeconomic position, concurrent environmental exposures), but the specific factors and mechanisms that define susceptibility remain uncertain $[120,124]$. In evaluating health risks associated with exposures, cumulative risk assessment initiatives have emphasized the importance of considering non-chemical stressors alongside chemicals, as well as interactions with intrinsic factors such as age and sex [125-128]. Such interactions may be important in the context of stress because effects of stressors will vary across the lifespan. For example, with respect to effects on the brain, stress may interfere with developmental programming during gestation and early childhood, contribute to depression in adults, and accelerate cognitive decline in the elderly [60]. Moreover, stress hormone responses to a standardized acute psychosocial stressor (the Trier Social Stress test) have been found to vary in relation to age and sex [129]. Accordingly, consideration of the stress context during specific life stages in each sex may be needed to more fully understand effects of pollutants and the modifying role of intrinsic and extrinsic factors (Fig. 4).

In this vein, a number of recent studies have directly examined the link between the stress context and pollutant effect modification, including examination of specific vulnerability periods in each sex. Higher PM2.5 exposure during the first trimester was associated with increased risk of wheeze among children with mothers who reported high prenatal stress [130]. Prenatal nitrate exposure at 7-19 and 33-40 weeks gestation was associated with asthma in boys exposed to high prenatal stress [131]. Combined exposure to PM2.5 and maternal stress was associated with mitochondrial DNA copy number in cord blood and placenta that also differed in a sex-specific manner [132]. Prenatal exposure to PM2.5 was associated with childhood asthma, with stronger effects observed in boys exposed prenatally to maternal stress [133]. Stronger associations between indicators of traffic-related air pollution $\left(\mathrm{NO}_{2}\right.$ and/or oxides of nitrogen) and asthma incidence have been reported

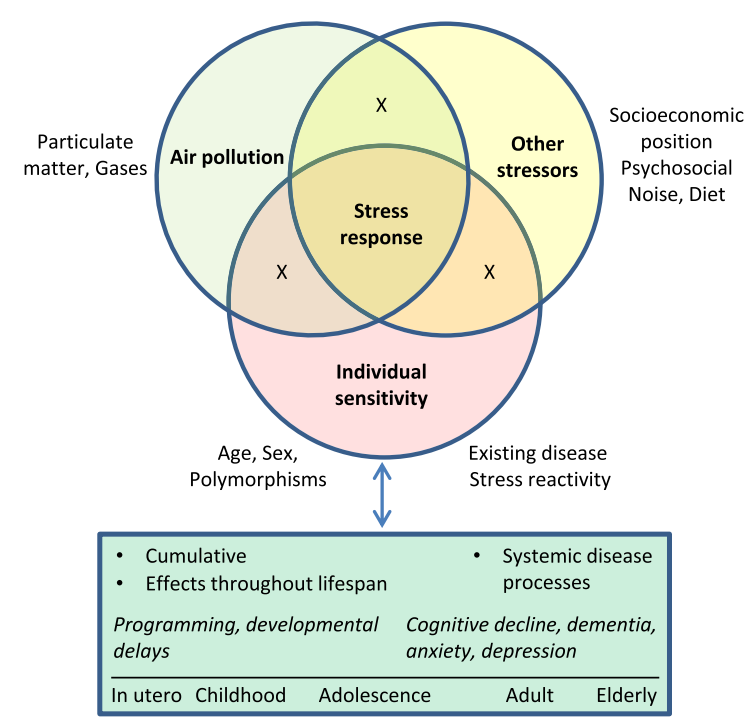

Fig. 4. Stress response as an integrator of effects of chemical and non-chemical stressors and individual sensitivity on brain health across the life course. Exposure to air pollution occurs in the context of other exposures, including stressors associated with socioeconomic position such crowding, crime, noise, and other hazards. Deleterious effects of exposure to chronic stressors may accumulate across the life course, and in turn may further increase vulnerability to subsequent exposures. Effects include impacts on fetal development, programming of future stress reactivity and disease susceptibility, and cumulative dysregulation of systemic neuroendocrine, cardiovascular, inflammatory, and metabolic processes that collectively contribute to disease. "X" represents interactions among factors. 
for children exposed to community violence [134] or living with higher parental stress [135], suggesting that heightened stress levels may exacerbate respiratory effects of pollutant exposure. Chronic stress was also associated with increased vulnerability to asthma exacerbations in children exposed to relatively low levels of traffic-related pollutants, an interaction not observed at higher pollutant levels [136]. Co-exposure to psychosocial stress was associated with greater risk of decreased lung function from exposure to traffic-related air pollutants in children [137] and adolescents [138]. In adults, stronger associations between PM2.5 and systolic blood pressure were found in individuals who reported high psychosocial stress assessed using a stress index that included neighborhood stress, acute life events, family caregiving stress, financial vulnerability, and unfair treatment [139], an association not found in a previous study that did not consider multiple sources and types of stress [140]. Collectively, these studies suggest that prior and concurrent exposures to nonchemical stressors exacerbate effects of air pollutants on respiratory and cardiovascular disease across life stages, including through prenatal programming of chronic diseases.

Whether the same holds true for brain health is currently unknown, but there is intriguing experimental and epidemiological evidence suggesting a role for neuroendocrine stress in modifying associations with environmental contaminants. Male pups exposed prenatally to diesel exhaust and maternal stress exhibited microglial activation as well as cognitive impairments, effects not observed in female pups or following exposure to either diesel exhaust or stress alone [141]. Interestingly, serum corticosterone was higher at postnatal day 1 only in the male pups exposed prenatally to stress, suggesting a possible early role in priming microglial immune responses to the pollutant. In a recent population study, the association between PM2.5 and lower cognitive scores was found to be stronger among older adults living in higher stress neighborhoods [142]. Earlier work showed that neighborhood psychosocial stressors or individual perceived stress strengthened associations between tibia or blood lead levels and poorer performance on cognitive tests in older adults $[143,144]$, consistent with experimental findings of a modifying role for stress in neuroendocrine effects of lead [145-147]. Co-exposure to air pollutants and noise, an important non-chemical stressor, was associated with greater impacts on cognitive function in adults aged 45-75 than would be expected by addition of independent effects, suggesting potential synergism [148]. Air pollutants have themselves been found to be associated with increased perceived stress [149], consistent with the notion that air pollution acts as a stressor and contributes to cumulative stress exposure. If prior or concurrent exposures to other stressors exacerbate the effects of pollutants on health outcomes such as cognitive impairment, impacts of pollutants may be greater in populations disproportionately exposed to stressors.

\section{IMPLICATIONS AND KNOWLEDGE GAPS}

Air pollution research has long been organ- or disease-specific, focused primarily on pulmonary and cardiometabolic diseases, and more recently on impacts on the brain including cognitive decline, dementia, and depression. Clearly, there is value in examining tissue- and disease-specific mechanisms; for example, understanding that nanoparticles may translocate to the brain via olfactory nerves [18] provides important insight into a potential route of exposure. Furthermore, it is clear that effects may differ according to dose and duration of exposure for different anatomical sites. In addition to such targeted studies, complementary approaches that consider effects of pollutants on systems that broadly impact the body are also needed to understand how the myriad health outcomes associated with exposure to air pollutants are connected, and to what extent they are driven by common initiating events. Despite distinct elements of neurological/mental health diseases, and considerable heterogeneity within a disease, a number of common underlying molecular and cellular mechanisms may increase susceptibility. These include dysregulated stress response systems [9], which are implicated also in a broad range of diseases that encompass those associated with air pollutants. It is unknown whether common initiating processes underlie the relationship between air pollutants and various diseases, although oxidative stress and inflammation have been identified as characteristic features of many disease states. Emerging evidence supports the notion that air pollutants act as chronic stressors, triggering stress response systems that, when chronically activated, contribute to a variety of disease states including those affecting the brain [8].

Assessing to what extent the health impacts of air pollutants are mediated through the stress axis may be helpful in improving our understanding of how 
pollutant exposure is associated with such a range of disease outcomes, and why adverse effects are seen in some individuals and not others. Because of their systemic nature, effects of chronic stressors will manifest in a variety of ways that depend not only on the nature of the stressor itself, but also on individual susceptibility. Exposure to stressors does not necessarily imply adverse consequences to the individual; rather, interindividual differences in susceptibility and resilience must be considered. There is substantial heterogeneity in stress reactivity in the human population [150]. Intrinsic factors such as age, sex, gender, stress reactivity, and existing disease, and extrinsic factors such as co-exposure to psychosocial and other stressors, may all potentially contribute to individual responses to pollutants. In rodent models, interstrain differences in stress axis function are associated with differences in lung injury and inflammatory response following exposure to ozone [151], suggesting that such variability may be relevant to susceptibility to pollutants. It will be important to assess to what extent interindividual differences are related to susceptibility to CNS impacts of air pollutants. Exposures during vulnerable windows of development are important determinants of future disease risk; indeed, stressors can produce epigenetic changes that influence future stress reactivity and morbidity, with some evidence that such effects may be transmitted across generations [152]. The timing, dose, pattern, and duration of exposure are likely to be important factors in determining effects, as seemingly opposing effects (e.g., pro- versus antiinflammatory effects of glucocorticoids [47]) may be produced depending upon context. In the population setting, composite measures such as allostatic load indices may be useful in assessing potential chronic effects of multiple stressors that act through diverse biological mechanisms. In addition, interactions with established risk factors warrant investigation.

If stressor action by air pollutants is an important contributor to health impacts, characteristics that define the nature, magnitude, and duration of the stress response warrant investigation. Recent findings from a panel study show associations between specific particulate constituents, especially watersoluble inorganic ions, and stress hormone levels [153]. Bacterial lipopolysaccharide (LPS) is a potent stimulator of the HPA axis via its inflammatory effects [154], and is a common constituent of ambient particulate matter. There are high levels of airborne LPS in Mexico City, where exposure to pollution has been associated with a range of adverse impacts on the brain [17]. As effects of particulate matter and ozone on the stress axis were additive in experimental models [44], the combined effects of exposure to multiple pollutants should be considered. Both population and toxicological studies will be needed to investigate and identify factors driving stress responses.

\section{CONCLUSION}

Chronic activation and dysfunction of the stress response system is a characteristic of many disease processes, including those associated with air pollution. Observations of similar systemic responses to particulate and gaseous pollutants suggest that the endocrine stress response could be a common mechanism contributing to extrapulmonary effects of pollutant exposure, including impacts on the brain [8, 44]. Further research is warranted to investigate the relative importance of stress responses and HPA axis dysregulation in contributing to air pollutant-induced disease progression. An exciting implication of this work is that air pollution, like other stressors, could be a modifiable risk factor for neurodegenerative and psychiatric disorders. Efforts aimed at reducing stressor exposure at individual, neighborhood, and community levels could have the added benefit of decreasing vulnerability to the adverse health impacts of air pollutants. Future epidemiological and experimental studies should provide insight into such questions.

\section{ACKNOWLEDGMENTS}

The author is grateful for the contributions of collaborators, postdoctoral fellows, and students to the studies that formed the basis of this paper. Thanks to Drs. Dalibor Breznan, Guillaume Pelletier, and Jith Thomas for their helpful comments on the manuscript. Thanks also to the anonymous peer-reviewers, whose generous and constructive comments helped improve this paper. The research projects that led to this work were funded by Health Canada through the Clean Air Regulatory Agenda.

Authors' disclosures available online (https:// www.j-alz.com/manuscript-disclosures/19-0015r2).

\section{REFERENCES}

[1] Brook RD, Rajagopalan S, Pope CA, III, Brook JR, Bhatnagar A, Diez-Roux AV, Holguin F, Hong Y, Luepker RV, Mittleman MA, Peters A, Siscovick D, Smith SC, Jr., Whitsel L, Kaufman JD (2010) Particulate matter air 
pollution and cardiovascular disease: an update to the scientific statement from the American Heart Association. Circulation 121, 2331-2378.

[2] Cohen AJ, Brauer M, Burnett R, Anderson HR, Frostad J, Estep K, Balakrishnan K, Brunekreef B, Dandona L, Dandona R, Feigin V, Freedman G, Hubbell B, Jobling A, Kan H, Knibbs L, Liu Y, Martin R, Morawska L, Pope CA, III, Shin H, Straif K, Shaddick G, Thomas M, Van DR, Van DA, Vos T, Murray CJL, Forouzanfar MH (2017) Estimates and 25-year trends of the global burden of disease attributable to ambient air pollution: an analysis of data from the Global Burden Of Diseases Study 2015. Lancet 389, 1907-1918.

[3] Whiteford HA, Ferrari AJ, Degenhardt L, Feigin V, Vos T (2015) The global burden of mental, neurological and substance use disorders: an analysis from the Global Burden of Disease Study 2010. Plos One 10, E0116820.

[4] Vos T, Flaxman AD, Naghavi M, Lozano R, Michaud C, Ezzati M, Shibuya K, Salomon JA, Abdalla S, Aboyans V, Abraham J, Ackerman I, Aggarwal R, Ahn SY, Ali MK, Alvarado M, Anderson HR, Anderson LM, Andrews KG, Atkinson C, Baddour LM, Bahalim AN, Barker-Collo S, Barrero LH, Bartels DH, Basanez MG, Baxter A, Bell ML, Benjamin EJ, Bennett D, Bernabe E, Bhalla K, Bhandari B, Bikbov B, Bin AA, Birbeck G, Black JA, Blencowe H, Blore JD, Blyth F, Bolliger I, Bonaventure A, Boufous S, Bourne R, Boussinesq M, Braithwaite T, Brayne C, Bridgett L, Brooker S, Brooks P, Brugha TS, Bryan-Hancock C, Bucello C, Buchbinder R, Buckle G, Budke CM, Burch M, Burney P, Burstein R, Calabria B, Campbell B, Canter CE, Carabin H, Carapetis J, Carmona L, Cella C, Charlson F, Chen H, Cheng AT, Chou D, Chugh SS, Coffeng LE, Colan SD, Colquhoun S, Colson KE, Condon J, Connor MD, Cooper LT, Corriere M, Cortinovis M, De Vaccaro KC, Couser W, Cowie BC, Criqui MH, Cross M, Dabhadkar KC, Dahiya M, Dahodwala N, Damsere-Derry J, Danaei G, Davis A, De LD, Degenhardt L, Dellavalle R, Delossantos A, Denenberg J, Derrett S, Des Jarlais DC, Dharmaratne SD, Dherani M, Diaz-Torne C, Dolk H, Dorsey ER, Driscoll T, Duber H, Ebel B, Edmond K, Elbaz A, Ali SE, Erskine H, Erwin PJ, Espindola P, Ewoigbokhan SE, Farzadfar F, Feigin V, Felson DT, Ferrari A, Ferri CP, Fevre EM, Finucane MM, Flaxman S, Flood L, Foreman K, Forouzanfar MH, Fowkes FG, Franklin R, Fransen M, Freeman MK, Gabbe BJ, Gabriel SE, Gakidou E, Ganatra HA, Garcia B, Gaspari F, Gillum RF, Gmel G, Gosselin R, Grainger R, Groeger J, Guillemin F, Gunnell D, Gupta R, Haagsma J, Hagan H, Halasa YA, Hall W, Haring D, Haro JM, Harrison JE, Havmoeller R, Hay RJ, Higashi H, Hill C, Hoen B, Hoffman H, Hotez PJ, Hoy D, Huang JJ, Ibeanusi SE, Jacobsen KH, James SL, Jarvis D, Jasrasaria R, Jayaraman S, Johns N, Jonas JB, Karthikeyan G, Kassebaum N, Kawakami N, Keren A, Khoo JP, King CH, Knowlton LM, Kobusingye O, Koranteng A, Krishnamurthi R, Lalloo R, Laslett LL, Lathlean T, Leasher JL, Lee YY, Leigh J, Lim SS, Limb E, Lin JK, Lipnick M, Lipshultz SE, Liu W, Loane M, Ohno SL, Lyons R, Ma J, Mabweijano J, Macintyre MF, Malekzadeh R, Mallinger L, Manivannan S, Marcenes W, March L, Margolis DJ, Marks GB, Marks R, Matsumori A, Matzopoulos R, Mayosi BM, Mcanulty JH, Mcdermott MM, Mcgill N, Mcgrath J, Medina-Mora ME, Meltzer M, Mensah GA, Merriman TR, Meyer AC, Miglioli V, Miller M, Miller TR, Mitchell PB, Mocumbi AO, Moffitt TE, Mokdad AA, Monasta L, Montico M, MoradiLakeh M, Moran A, Morawska L, Mori R, Murdoch ME,
Mwaniki MK, Naidoo K, Nair MN, Naldi L, Narayan KM, Nelson PK, Nelson RG, Nevitt MC, Newton CR, Nolte S, Norman P, Norman R, O'Donnell M, O'Hanlon S, Olives C, Omer SB, Ortblad K, Osborne R, Ozgediz D, Page A, Pahari B, Pandian JD, Rivero AP, Patten SB, Pearce N, Padilla RP, Perez-Ruiz F (2012) Years lived with disability (YLDs) for 1160 sequelae of 289 diseases and injuries 1990-2010: a systematic analysis for the Global Burden of Disease Study 2010. Lancet 380, 2163-2196.

[5] Power MC, Adar SD, Yanosky JD, Weuve J (2016) Exposure to air pollution as a potential contributor to cognitive function, cognitive decline, brain imaging, and dementia: a systematic review of epidemiologic research. Neurotoxicology 56, 235-253.

[6] Allen JL, Klocke C, Morris-Schaffer K, Conrad K, Sobolewski M, Cory-Slechta DA (2017) Cognitive effects of air pollution exposures and potential mechanistic underpinnings. Curr Environ Health Rep 4, 180-191.

[7] Block ML, Elder A, Auten RL, Bilbo SD, Chen H, Chen JC, Cory-Slechta DA, Costa D, Diaz-Sanchez D, Dorman DC, Gold DR, Gray K, Jeng HA, Kaufman JD, Kleinman MT, Kirshner A, Lawler C, Miller DS, Nadadur SS, Ritz B, Semmens EO, Tonelli LH, Veronesi B, Wright RO, Wright RJ (2012) The outdoor air pollution and brain health workshop. Neurotoxicology 33, 972-984.

[8] Thomson EM (2014) Neurobehavioral and metabolic impacts of inhaled pollutants: a role for the hypothalamicpituitary-adrenal axis? Endocrine Disruptors 1, 1-5.

[9] Ross JA, Gliebus G, Van Bockstaele EJ (2018) Stress induced neural reorganization: a conceptual framework linking depression and Alzheimer's disease. Prog Neuropsychopharmacol Biol Psychiatry 85, 136-151.

[10] Burnett R, Chen H, Szyszkowicz M, Fann N, Hubbell B, Pope CA, III, Apte JS, Brauer M, Cohen A, Weichenthal S, Coggins J, Di Q, Brunekreef B, Frostad J, Lim SS, Kan H, Walker KD, Thurston GD, Hayes RB, Lim CC, Turner MC, Jerrett M, Krewski D, Gapstur SM, Diver WR, Ostro B, Goldberg D, Crouse DL, Martin RV, Peters P, Pinault L, Tjepkema M, Van DA, Villeneuve PJ, Miller $\mathrm{AB}$, Yin P, Zhou M, Wang L, Janssen NAH, Marra M, Atkinson RW, Tsang H, Quoc TT, Cannon JB, Allen RT, Hart JE, Laden F, Cesaroni G, Forastiere F, Weinmayr G, Jaensch A, Nagel G, Concin H, Spadaro JV (2018) Global estimates of mortality associated with long-term exposure to outdoor fine particulate matter. Proc Natl Acad Sci USA 115, 9592-9597.

[11] Thomson EM, Breznan D, Karthikeyan S, MackinnonRoy C, Vuong NQ, Dabek-Zlotorzynska E, Celo V, Charland JP, Kumarathasan P, Brook JR, Vincent R (2016) Contrasting biological potency of particulate matter collected at sites impacted by distinct industrial sources. Part Fibre Toxicol 13, 65.

[12] Thomson EM, Breznan D, Karthikeyan S, MackinnonRoy C, Charland JP, Dabek-Zlotorzynska E, Celo V, Kumarathasan P, Brook JR, Vincent R (2015) Cytotoxic and inflammatory potential of size-fractionated particulate matter collected repeatedly within a small urban area. Part Fibre Toxicol 12, 24.

[13] Steenhof M, Gosens I, Strak M, Godri KJ, Hoek G, Cassee FR, Mudway IS, Kelly FJ, Harrison RM, Lebret E, Brunekreef B, Janssen NA, Pieters RH (2011) In vitro toxicity of particulate matter (PM) collected at different sites in the Netherlands is associated with PM composition, size fraction and oxidative potential-The RAPTES Project. Part Fibre Toxicol 8, 26. 
[14] Peng RD, Dominici F, Pastor-Barriuso R, Zeger SL, Samet JM (2005) Seasonal analyses of air pollution and mortality in 100 US cities. Am J Epidemiol 161, 585-594.

[15] Zanobetti A, Franklin M, Koutrakis P, Schwartz J (2009) Fine particulate air pollution and its components in association with cause-specific emergency admissions. Environ Health 8, 58.

[16] Grahame TJ, Schlesinger RB (2007) Health effects of airborne particulate matter: do we know enough to consider regulating specific particle types or sources? Inhal Toxicol 19, 457-481.

[17] Calderon-Garciduenas L, Azzarelli B, Acuna H, Garcia R, Gambling TM, Osnaya N, Monroy S, DEL Tizapantzi MR, Carson JL, Villarreal-Calderon A, Rewcastle B (2002) Air pollution and brain damage. Toxicol Pathol 30, 373-389.

[18] Elder A, Gelein R, Silva V, Feikert T, Opanashuk L, Carter J, Potter R, Maynard A, Ito Y, Finkelstein J, Oberdorster G (2006) Translocation of inhaled ultrafine manganese oxide particles to the central nervous system. Environ Health Perspect 114, 1172-1178.

[19] Lucchini RG, Dorman DC, Elder A, Veronesi B (2012) Neurological impacts from inhalation of pollutants and the nose-brain connection. Neurotoxicology 33, 838-841.

[20] Heusinkveld HJ, Wahle T, Campbell A, Westerink RHS, Tran L, Johnston H, Stone V, Cassee FR, Schins RPF (2016) Neurodegenerative and neurological disorders by small inhaled particles. Neurotoxicology 56, 94-106.

[21] Santiago-Lopez D, Bautista-Martinez JA, ReyesHernandez CI, Aguilar-Martinez M, Rivas-Arancibia S (2010) Oxidative stress, progressive damage in the substantia nigra and plasma dopamine oxidation, in rats chronically exposed to ozone. Toxicol Lett 197, 193-200.

[22] Rivas-Arancibia S, Vazquez-Sandoval R, GonzalezKladiano D, Schneider-Rivas S, Lechuga-Guerrero A (1998) Effects of ozone exposure in rats on memory and levels of brain and pulmonary superoxide dismutase. Environ Res 76, 33-39.

[23] Thomson EM, Kumarathasan P, Calderon-Garciduenas L, Vincent R (2007) Air pollution alters brain and pituitary endothelin-1 and inducible nitric oxide synthase gene expression. Environ Res 105, 224-233.

[24] Mumaw CL, Levesque S, Mcgraw C, Robertson S, Lucas S, Stafflinger JE, Campen MJ, Hall P, Norenberg JP, Anderson T, Lund AK, Mcdonald JD, Ottens AK, Block ML (2016) Microglial priming through the lung-brain axis: the role of air pollution-induced circulating factors. FASEB J 30, 1880-1891.

[25] Pryor WA, Squadrito GL, Friedman M (1995) The cascade mechanism to explain ozone toxicity: the role of lipid ozonation products. Free Radic Biol Med 19, 935-941.

[26] Bromberg PA (2016) Mechanisms of the acute effects of inhaled ozone in humans. Biochim Biophys Acta 1860, 2771-2781.

[27] Zhang X, Chen X, Zhang X (2018) The impact of exposure to air pollution on cognitive performance. Proc Natl Acad Sci U S A 115, 9193-9197.

[28] Chen JC, Schwartz J (2009) Neurobehavioral effects of ambient air pollution on cognitive performance in US adults. Neurotoxicology 30, 231-239.

[29] Gatto NM, Henderson VW, Hodis HN, St John JA, Lurmann F, Chen JC, Mack WJ (2014) Components of air pollution and cognitive function in middle-aged and older adults in Los Angeles. Neurotoxicology 40, 1-7.

[30] Chen H, Kwong JC, Copes R, Hystad P, Van DA, Tu K, Brook JR, Goldberg MS, Martin RV, Murray BJ, Wilton
AS, Kopp A, Burnett RT (2017) Exposure to ambient air pollution and the incidence of dementia: a populationbased cohort study. Environ Int 108, 271-277.

[31] Cleary EG, Cifuentes M, Grinstein G, Brugge D, Shea TB (2018) Association of low-level ozone with cognitive decline in older adults. J Alzheimers Dis 61, 67-78.

[32] Kioumourtzoglou MA, Power MC, Hart JE, Okereke OI, Coull BA, Laden F, Weisskopf MG (2017) The association between air pollution and onset of depression among middle-aged and older women. Am J Epidemiol 185, 801-809.

[33] Lim YH, Kim H, Kim JH, Bae S, Park HY, Hong YC (2012) Air pollution and symptoms of depression in elderly adults. Environ Health Perspect 120, 1023-1028.

[34] Power MC, Kioumourtzoglou MA, Hart JE, Okereke OI, Laden F, Weisskopf MG (2015) The relation between past exposure to fine particulate air pollution and prevalent anxiety: observational cohort study. BMJ 350, H1111.

[35] Pun VC, Manjourides J, Suh H (2017) Association of ambient air pollution with depressive and anxiety symptoms in older adults: results from the NSHAP Study. Environ Health Perspect 125, 342-348.

[36] Kim Y, Ng CFS, Chung Y, Kim H, Honda Y, Guo YL, Lim YH, Chen BY, Page LA, Hashizume M (2018) Air pollution and suicide in 10 cities in Northeast Asia: a timestratified case-crossover analysis. Environ Health Perspect 126, 037002.

[37] Szyszkowicz M, Willey JB, Grafstein E, Rowe BH, Colman I (2010) Air pollution and emergency department visits for suicide attempts in Vancouver, Canada. Environ Health Insights 4, 79-86.

[38] Kim Y, Myung W, Won HH, Shim S, Jeon HJ, Choi J, Carroll BJ, Kim DK (2015) Association between air pollution and suicide in South Korea: a nationwide study. Plos One 10, E0117929.

[39] Croze ML, Zimmer L (2018) Ozone atmospheric pollution and Alzheimer's disease: from epidemiological facts to molecular mechanisms. J Alzheimers Dis 62, 503-522.

[40] Zhao T, Markevych I, Romanos M, Nowak D, Heinrich J (2018) Ambient ozone exposure and mental health: a systematic review of epidemiological studies. Environ Res $\mathbf{1 6 5}, 459-472$.

[41] Campbell A, Oldham M, Becaria A, Bondy SC, Meacher D, Sioutas C, Misra C, Mendez LB, Kleinman M (2005) Particulate matter in polluted air may increase biomarkers of inflammation in mouse brain. Neurotoxicology 26, 133-140.

[42] Fonken LK, Xu X, Weil ZM, Chen G, Sun Q, Rajagopalan S, Nelson RJ (2011) Air pollution impairs cognition, provokes depressive-like behaviors and alters hippocampal cytokine expression and morphology. Mol Psychiatry 16, 987-95, 973.

[43] Levesque S, Surace MJ, Mcdonald J, Block ML (2011) Air pollution and the brain: subchronic diesel exhaust exposure causes neuroinflammation and elevates early markers of neurodegenerative disease. J Neuroinflammation $\mathbf{8}, 105$.

[44] Thomson EM, Vladisavljevic D, Mohottalage S, Kumarathasan P, Vincent R (2013) Mapping acute systemic effects of inhaled particulate matter and ozone: multiorgan gene expression and glucocorticoid activity. Toxicol Sci 135, 169-181.

[45] Chrousos GP (2009) Stress and disorders of the stress system. Nat Rev Endocrinol 5, 374-381.

[46] Cain DW, Cidlowski JA (2017) Immune regulation by glucocorticoids. Nat Rev Immunol 17, 233-247. 
[47] Sorrells SF, Sapolsky RM (2007) An inflammatory review of glucocorticoid actions in the CNS. Brain Behav Immun 21, 259-272.

[48] Chrousos GP, Kino T (2009) Glucocorticoid signaling in the cell. expanding clinical implications to complex human behavioral and somatic disorders. Ann N Y Acad Sci 1179, 153-166.

[49] Sirivelu MP, Mohankumar SM, Wagner JG, Harkema JR, Mohankumar PS (2006) Activation of the stress axis and neurochemical alterations in specific brain areas by concentrated ambient particle exposure with concomitant allergic airway disease. Environ Health Perspect 114, 870-874

[50] Lange M, Pagotto U, Renner U, Arzberger T, Oeckler R, Stalla GK (2002) The role of endothelins in the regulation of pituitary function. Exp Clin Endocrinol Diabetes 110, 103-112.

[51] Gackiere F, Saliba L, Baude A, Bosler O, Strube C (2011) Ozone inhalation activates stress-responsive regions of the CNS. J Neurochem 117, 961-972.

[52] Martrette JM, Thornton SN, Trabalon M (2011) Prolonged ozone exposure effects behaviour, hormones and respiratory muscles in young female rats. Physiol Behav 103, 302-307.

[53] Bass V, Gordon CJ, Jarema KA, Macphail RC, Cascio WE, Phillips PM, Ledbetter AD, Schladweiler MC, Andrews D, Miller D, Doerfler DL, Kodavanti UP (2013) Ozone induces glucose intolerance and systemic metabolic effects in young and aged brown Norway rats. Toxicol Appl Pharmacol 273, 551-560.

[54] Thomson EM, Pal S, Guenette J, Wade MG, Atlas E, Holloway AC, Williams A, Vincent R (2016) Ozone inhalation provokes glucocorticoid-dependent and -independent effects on inflammatory and metabolic pathways. Toxicol Sci 152, 17-28.

[55] Henriquez AR, Snow SJ, Schladweiler MC, Miller CN, Dye JA, Ledbetter AD, Richards JE, Mauge-Lewis K, Mcgee MA, Kodavanti UP (2018) Adrenergic and glucocorticoid receptor antagonists reduce ozone-induced lung injury and inflammation. Toxicol Appl Pharmacol 339, 161-171.

[56] Miller DB, Ghio AJ, Karoly ED, Bell LN, Snow SJ, Madden MC, Soukup J, Cascio WE, Gilmour MI, Kodavanti UP (2016) Ozone exposure increases circulating stress hormones and lipid metabolites in humans. Am J Respir Crit Care Med 193, 1382-1391.

[57] Li H, Cai J, Chen R, Zhao Z, Ying Z, Wang L, Chen J, Hao K, Kinney PL, Chen H, Kan H (2017) Particulate matter exposure and stress hormone levels: a randomized, doubleblind, crossover trial of air purification. Circulation 136, 618-627.

[58] Mcewen BS, Nasca C, Gray JD (2016) Stress effects on neuronal structure: hippocampus, amygdala, and prefrontal cortex. Neuropsychopharmacology 41, 3-23.

[59] De Kloet ER (2004) Hormones and the stressed brain. Ann $N$ Y Acad Sci 1018, 1-15.

[60] Lupien SJ, Mcewen BS, Gunnar MR, Heim C (2009) Effects of stress throughout the lifespan on the brain, behaviour and cognition. Nat Rev Neurosci 10, 434-445.

[61] Gaspar P, Cases O, Maroteaux L (2003) The developmental role of serotonin: news from mouse molecular genetics. Nat Rev Neurosci 4, 1002-1012.

[62] Mcewen BS (2005) Glucocorticoids, depression, and mood disorders: structural remodeling in the brain. Metabolism 54(5 Suppl 1), 20-23.
[63] Caruso A, Nicoletti F, Mango D, Saidi A, Orlando R, Scaccianoce S (2018) Stress as risk factor for Alzheimer's disease. Pharmacol Res 132, 130-134.

[64] Pittenger C, Duman RS (2008) Stress, depression, and neuroplasticity: a convergence of mechanisms. Neuropsychopharmacology 33, 88-109.

[65] Lupien SJ, De LM, De SS, Convit A, Tarshish C, Nair NP, Thakur M, Mcewen BS, Hauger RL, Meaney MJ (1998) Cortisol levels during human aging predict hippocampal atrophy and memory deficits. Nat Neurosci 1, 69-73.

[66] Gotlib IH, Joormann J, Minor KL, Hallmayer J (2008) HPA axis reactivity: a mechanism underlying the associations among 5-HTTLPR, stress, and depression. Biol Psychiatry 63, 847-851.

[67] Sapolsky RM, Krey LC, Mcewen BS (1986) The neuroendocrinology of stress and aging: the glucocorticoid cascade hypothesis. Endocr Rev 7, 284-301.

[68] Liu B, Liu J, Wang M, Zhang Y, Li L (2017) From serotonin to neuroplasticity: evolvement of theories for major depressive disorder. Front Cell Neurosci 11, 305.

[69] Jacobson L, Sapolsky R (1991) The role of the hippocampus in feedback regulation of the hypothalamicpituitary-adrenocortical axis. Endocr Rev 12, 118-134.

[70] Landfield PW, Waymire JC, Lynch G (1978) Hippocampal aging and adrenocorticoids: quantitative correlations. Science 202, 1098-1102.

[71] Landfield PW, Baskin RK, Pitler TA (1981) Brain aging correlates: retardation by hormonal-pharmacological treatments. Science 214, 581-584.

[72] Issa AM, Rowe W, Gauthier S, Meaney MJ (1990) Hypothalamic-pituitary-adrenal activity in aged, cognitively impaired and cognitively unimpaired rats. $J$ Neurosci 10, 3247-3254.

[73] Alonso G (2000) Prolonged corticosterone treatment of adult rats inhibits the proliferation of oligodendrocyte progenitors present throughout white and gray matter regions of the brain. Glia 31, 219-231.

[74] Chetty S, Friedman AR, Taravosh-Lahn K, Kirby ED, Mirescu C, Guo F, Krupik D, Nicholas A, Geraghty A, Krishnamurthy A, Tsai MK, Covarrubias D, Wong A, Francis D, Sapolsky RM, Palmer TD, Pleasure D, Kaufer D (2014) Stress and glucocorticoids promote oligodendrogenesis in the adult hippocampus. Mol Psychiatry 19, 1275-1283.

[75] Pires P, Santos A, Vives-Gilabert Y, Webb SM, Sainz-Ruiz A, Resmini E, Crespo I, De Juan-Delago M, GomezAnson B (2015) White matter alterations in the brains of patients with active, remitted, and cured cushing syndrome: a DTI study. AJNR Am J Neuroradiol 36, 1043-1048.

[76] Kulstad JJ, Mcmillan PJ, Leverenz JB, Cook DG, Green PS, Peskind ER, Wilkinson CW, Farris W, Mehta PD, Craft $S$ (2005) Effects of chronic glucocorticoid administration on insulin-degrading enzyme and amyloid-beta peptide in the aged macaque. J Neuropathol Exp Neurol 64, 139-146.

[77] Yau JL, Noble J, Kenyon CJ, Hibberd C, Kotelevtsev Y, Mullins JJ, Seckl JR (2001) Lack of tissue glucocorticoid reactivation in 11 beta -hydroxysteroid dehydrogenase type 1 knockout mice ameliorates age-related learning impairments. Proc Natl Acad Sci U S A 98, 4716-4721.

[78] Sterner EY, Kalynchuk LE (2010) Behavioral and neurobiological consequences of prolonged glucocorticoid exposure in rats: relevance to depression. Prog Neuropsychopharmacol Biol Psychiatry 34, 777-790. 
[79] Lante F, Chafai M, Raymond EF, Pereira AR, Mouska X, Kootar S, Barik J, Bethus I, Marie H (2015) Subchronic glucocorticoid receptor inhibition rescues early episodic memory and synaptic plasticity deficits in a mouse model of Alzheimer's disease. Neuropsychopharmacology 40, 1772-1781.

[80] Silverman MN, Sternberg EM (2012) Glucocorticoid regulation of inflammation and its functional correlates: from HPA axis to glucocorticoid receptor dysfunction. Ann NY Acad Sci 1261, 55-63.

[81] Vogelzangs N, Suthers K, Ferrucci L, Simonsick EM, Ble A, Schrager M, Bandinelli S, Lauretani F, Giannelli SV, Penninx BW (2007) Hypercortisolemic depression is associated with the metabolic syndrome in late-life. Psychoneuroendocrinology 32, 151-159.

[82] Pan A, Keum N, Okereke OI, Sun Q, Kivimaki M, Rubin RR, Hu FB (2012) Bidirectional association between depression and metabolic syndrome: a systematic review and meta-analysis of epidemiological studies. Diabetes Care 35, 1171-1180.

[83] Dunbar JA, Reddy P, Davis-Lameloise N, Philpot B, Laatikainen T, Kilkkinen A, Bunker SJ, Best JD, Vartiainen E, Kai LS, Janus ED (2008) Depression: an important comorbidity with metabolic syndrome in a general population. Diabetes Care 31, 2368-2373.

[84] Chrousos GP (2000) The role of stress and the hypothalamic-pituitary-adrenal axis in the pathogenesis of the metabolic syndrome: neuro-endocrine and target tissue-related causes. Int J Obes Relat Metab Disord 24 Suppl 2, S50-S55.

[85] Macfarlane DP, Forbes S, Walker BR (2008) Glucocorticoids and fatty acid metabolism in humans: fuelling fat redistribution in the metabolic syndrome. $J$ Endocrinol 197, 189-204.

[86] Zhao WQ, Alkon DL (2001) Role of insulin and insulin receptor in learning and memory. Mol Cell Endocrinol 177, 125-134.

[87] Talbot K, Wang HY, Kazi H, Han LY, Bakshi KP, Stucky A, Fuino RL, Kawaguchi KR, Samoyedny AJ, Wilson RS, Arvanitakis Z, Schneider JA, Wolf BA, Bennett DA, Trojanowski JQ, Arnold SE (2012) Demonstrated brain insulin resistance in Alzheimer's disease patients is associated with IGF-1 resistance, IRS-1 dysregulation, and cognitive decline. J Clin Invest 122, 1316-1338.

[88] Farris W, Mansourian S, Chang Y, Lindsley L, Eckman EA, Frosch MP, Eckman CB, Tanzi RE, Selkoe DJ, Guenette S (2003) Insulin-degrading enzyme regulates the levels of insulin, amyloid beta-protein, and the betaamyloid precursor protein intracellular domain in vivo. Proc Natl Acad Sci U S A 100, 4162-4167.

[89] Convit A, Wolf OT, Tarshish C, De Leon MJ (2003) Reduced glucose tolerance is associated with poor memory performance and hippocampal atrophy among normal elderly. Proc Natl Acad Sci U S A 100, 2019-2022.

[90] Willette AA, Bendlin BB, Starks EJ, Birdsill AC, Johnson SC, Christian BT, Okonkwo OC, La RA, Hermann BP, Koscik RL, Jonaitis EM, Sager MA, Asthana S (2015) Association of insulin resistance with cerebral glucose uptake in late middle-aged adults at risk for Alzheimer disease. JAMA Neurol 72, 1013-1020.

[91] Shpilberg Y, Beaudry JL, D'Souza A, Campbell JE, Peckett A, Riddell MC (2012) A rodent model of rapid-onset diabetes induced by glucocorticoids and high-fat feeding. Dis Model Mech 5, 671-680.
[92] Brook RD, Newby DE, Rajagopalan S (2017) Air pollution and cardiometabolic disease: an update and call for clinical trials. Am J Hypertens 31, 1-10.

[93] Sun Q, Yue P, Deiuliis JA, Lumeng CN, Kampfrath T, Mikolaj MB, Cai Y, Ostrowski MC, Lu B, Parthasarathy S, Brook RD, Moffatt-Bruce SD, Chen LC, Rajagopalan S (2009) Ambient air pollution exaggerates adipose inflammation and insulin resistance in a mouse model of diet-induced obesity. Circulation 119, 538-546.

[94] Vella RE, Pillon NJ, Zarrouki B, Croze ML, Koppe L, Guichardant M, Pesenti S, Chauvin MA, Rieusset J, Geloen A, Soulage CO (2015) Ozone exposure triggers insulin resistance through muscle c-Jun $\mathrm{N}$-terminal kinase activation. Diabetes 64, 1011-1024.

[95] Miller DB, Snow SJ, Schladweiler MC, Richards JE, Ghio AJ, Ledbetter AD, Kodavanti UP (2016) Acute ozoneinduced pulmonary and systemic metabolic effects are diminished in adrenalectomized rats. Toxicol Sci 150, 312-322.

[96] Thomson EM, Pilon S, Guenette J, Williams A, Holloway AC (2018) Ozone modifies the metabolic and endocrine response to glucose: reproduction of effects with the stress hormone corticosterone. Toxicol Appl Pharmacol 342, 31-38.

[97] Costa LG, Cole TB, Coburn J, Chang YC, Dao K, Roque PJ (2017) Neurotoxicity of traffic-related air pollution. Neurotoxicology 59, 133-139.

[98] Woodward N, Finch CE, Morgan TE (2015) Traffic-related air pollution and brain development. AIMS Environ Sci 2 , 353-373.

[99] Guxens M, Aguilera I, Ballester F, Estarlich M, FernandezSomoano A, Lertxundi A, Lertxundi N, Mendez MA, Tardon A, Vrijheid M, Sunyer J (2012) Prenatal exposure to residential air pollution and infant mental development: modulation by antioxidants and detoxification factors. Environ Health Perspect 120, 144-149.

[100] Hou L, Zhu ZZ, Zhang X, Nordio F, Bonzini M, Schwartz J, Hoxha M, Dioni L, Marinelli B, Pegoraro V, Apostoli P, Bertazzi PA, Baccarelli A (2010) Airborne particulate matter and mitochondrial damage: a cross-sectional study. Environ Health 9, 48.

[101] Janssen BG, Munters E, Pieters N, Smeets K, Cox B, Cuypers A, Fierens F, Penders J, Vangronsveld J, Gyselaers W, Nawrot TS (2012) Placental mitochondrial DNA content and particulate air pollution during in utero life. Environ Health Perspect 120, 1346-1352.

[102] Lin MT, Beal MF (2006) Mitochondrial dysfunction and oxidative stress in neurodegenerative diseases. Nature $\mathbf{4 4 3}$, 787-795.

[103] Colicino E, Wilson A, Frisardi MC, Prada D, Power MC, Hoxha M, Dioni L, Spiro A, Vokonas PS, Weisskopf MG, Schwartz JD, Baccarelli AA (2017) Telomere length, longterm black carbon exposure, and cognitive function in a cohort of older men: the VA Normative Aging Study. Environ Health Perspect 125, 76-81.

[104] Martens DS, Nawrot TS (2018) Ageing at the level of telomeres in association to residential landscape and air pollution at home and work: a review of the current evidence. Toxicol Lett 298, 42-52.

[105] Dorado-Martinez C, Paredes-Carbajal C, Mascher D, Borgonio-Perez G, Rivas-Arancibia S (2001) Effects of different ozone doses on memory, motor activity and lipid peroxidation levels, in rats. Int J Neurosci 108, 149-161. 
[106] Rivas-Arancibia S, Guevara-Guzman R, Lopez-Vidal Y, Rodriguez-Martinez E, Zanardo-Gomes M, Ngoa-Perez M, Raisman-Vozari R (2010) Oxidative stress caused by ozone exposure induces loss of brain repair in the hippocampus of adult rats. Toxicol Sci 113, 187-197.

[107] Woodward NC, Pakbin P, Saffari A, Shirmohammadi F, Haghani A, Sioutas C, Cacciottolo M, Morgan TE, Finch CE (2017) Traffic-related air pollution impact on mouse brain accelerates myelin and neuritic aging changes with specificity for CA1 neurons. Neurobiol Aging 53, 48-58.

[108] Woodward NC, Haghani A, Johnson RG, Hsu TM, Saffari A, Sioutas C, Kanoski SE, Finch CE, Morgan TE (2018) Prenatal and early life exposure to air pollution induced hippocampal vascular leakage and impaired neurogenesis in association with behavioral deficits. Transl Psychiatry 8, 261.

[109] Fonken LK, Frank MG, Gaudet AD, Maier SF (2018) Stress and aging act through common mechanisms to elicit neuroinflammatory priming. Brain Behav Immun 73, 133-148.

[110] Frank MG, Thompson BM, Watkins LR, Maier SF (2012) Glucocorticoids mediate stress-induced priming of microglial pro-inflammatory responses. Brain Behav Immun 26, 337-345.

[111] Epel ES, Blackburn EH, Lin J, Dhabhar FS, Adler NE, Morrow JD, Cawthon RM (2004) Accelerated telomere shortening in response to life stress. Proc Natl Acad Sci U S A 101, 17312-17315.

[112] Angelier F, Costantini D, Blevin P, Chastel O (2018) Do glucocorticoids mediate the link between environmental conditions and telomere dynamics in wild vertebrates? A review. Gen Comp Endocrinol 256, 99-111.

[113] Epel ES (2009) Psychological and metabolic stress: A recipe for accelerated cellular aging? Hormones (Athens) 8, 7-22.

[114] Du J, Wang Y, Hunter R, Wei Y, Blumenthal R, Falke C, Khairova R, Zhou R, Yuan P, Machado-Vieira R, Mcewen BS, Manji HK (2009) Dynamic regulation of mitochondrial function by glucocorticoids. Proc Natl Acad Sci U S A 106, 3543-3548.

[115] Mcewen BS, Stellar E (1993) Stress and the individual. mechanisms leading to disease. Arch Intern Med 153, 2093-2101.

[116] Juster RP, Mcewen BS, Lupien SJ (2010) Allostatic load biomarkers of chronic stress and impact on health and cognition. Neurosci Biobehav Rev 35, 2-16.

[117] Seeman TE, Mcewen BS, Rowe JW, Singer BH (2001) Allostatic load as a marker of cumulative biological risk: macarthur studies of successful aging. Proc Natl Acad Sci U S A 98, 4770-4775.

[118] Kobrosly RW, Seplaki CL, Jones CM, Van WE (2012) Physiologic dysfunction scores and cognitive function test performance in U.S. adults. Psychosom Med 74, 81-88.

[119] Evans GW, Schamberg MA (2009) Childhood poverty, chronic stress, and adult working memory. Proc Natl Acad Sci U S A 106, 6545-6549.

[120] O'Neill MS, Jerrett M, Kawachi I, Levy JI, Cohen AJ, Gouveia N, Wilkinson P, Fletcher T, Cifuentes L, Schwartz J (2003) Health, wealth, and air pollution: advancing theory and methods. Environ Health Perspect 111, 1861-1870.

[121] Egorov AI, Griffin SM, Converse RR, Styles JN, Sams EA, Wilson A, Jackson LE, Wade TJ (2017) Vegetated land cover near residence is associated with reduced allostatic load and improved biomarkers of neuroendocrine, metabolic and immune functions. Environ Res 158, 508-521.

[122] Crouse DL, Balram A, Hystad P, Pinault L, Van Den Bosch M, Chen H, Rainham D, Thomson EM, Close CH, Van DA, Martin RV, Menard R, Robichaud A, Villeneuve PJ (2018) Associations between living near water and risk of mortality among urban Canadians. Environ Health Perspect 126, 077008.

[123] Van Den Bosch M, Ode SA (2017) Urban natural environments as nature-based solutions for improved public health - a systematic review of reviews. Environ Res 158, 373-384.

[124] Sacks JD, Stanek LW, Luben TJ, Johns DO, Buckley BJ, Brown JS, Ross M (2011) Particulate matter-induced health effects: who is susceptible? Environ Health Perspect 119, 446-454.

[125] Lewis AS, Sax SN, Wason SC, Campleman SL (2011) Non-chemical stressors and cumulative risk assessment: an overview of current initiatives and potential air pollutant interactions. Int J Environ Res Public Health 8, 2020-2073.

[126] Rider CV, Dourson ML, Hertzberg RC, Mumtaz MM, Price PS, Simmons JE (2012) Incorporating nonchemical stressors into cumulative risk assessments. Toxicol Sci 127, 10-17.

[127] Clougherty JE, Kubzansky LD (2009) A framework for examining social stress and susceptibility to air pollution in respiratory health. Environ Health Perspect 117, 1351-1358.

[128] Cowell WJ, Wright RJ (2017) Sex-specific effects of combined exposure to chemical and non-chemical stressors on neuroendocrine development: a review of recent findings and putative mechanisms. Curr Environ Health Rep 4, 415-425.

[129] Kudielka BM, Buske-Kirschbaum A, Hellhammer DH, Kirschbaum C (2004) HPA axis responses to laboratory psychosocial stress in healthy elderly adults, younger adults, and children: impact of age and gender. Psychoneuroendocrinology 29, 83-98.

[130] Rosa MJ, Just AC, Kloog I, Pantic I, Schnaas L, Lee A, Bose S, Chiu YM, Hsu HL, Coull B, Schwartz J, Cohen S, Tellez Rojo MM, Wright RO, Wright RJ (2017) Prenatal particulate matter exposure and wheeze in Mexican children: Effect modification by prenatal psychosocial stress. Ann Allergy Asthma Immunol 119, 232-237.

[131] Bose S, Chiu YM, Hsu HL, Di Q, Rosa MJ, Lee A, Kloog I, Wilson A, Schwartz J, Wright RO, Cohen S, Coull BA, Wright RJ (2017) Prenatal nitrate exposure and childhood asthma. Influence of maternal prenatal stress and fetal sex. Am J Respir Crit Care Med 196, 1396-1403.

[132] Brunst KJ, Sanchez-Guerra M, Chiu YM, Wilson A, Coull BA, Kloog I, Schwartz J, Brennan KJ, Bosquet EM, Wright RO, Baccarelli AA, Wright RJ (2018) Prenatal particulate matter exposure and mitochondrial dysfunction at the maternal-fetal interface: effect modification by maternal lifetime trauma and child sex. Environ Int 112, 49-58.

[133] Lee A, Leon Hsu HH, Mathilda Chiu YH, Bose S, Rosa MJ, Kloog I, Wilson A, Schwartz J, Cohen S, Coull BA, Wright RO, Wright RJ (2018) Prenatal fine particulate exposure and early childhood asthma: effect of maternal stress and fetal sex. J Allergy Clin Immunol 141, 1880-1886. 
[134] Clougherty JE, Levy JI, Kubzansky LD, Ryan PB, Suglia SF, Canner MJ, Wright RJ (2007) Synergistic effects of traffic-related air pollution and exposure to violence on urban asthma etiology. Environ Health Perspect 115, 1140-1146.

[135] Shankardass K, Mcconnell R, Jerrett M, Milam J, Richardson J, Berhane K (2009) Parental stress increases the effect of traffic-related air pollution on childhood asthma incidence. Proc Natl Acad Sci U S A 106, 12406-12411.

[136] Chen E, Schreier HM, Strunk RC, Brauer M (2008) Chronic traffic-related air pollution and stress interact to predict biologic and clinical outcomes in asthma. Environ Health Perspect 116, 970-975.

[137] Islam T, Urman R, Gauderman WJ, Milam J, Lurmann F, Shankardass K, Avol E, Gilliland F, Mcconnell R (2011) Parental stress increases the detrimental effect of traffic exposure on children's lung function. Am J Respir Crit Care Med 184, 822-827.

[138] Bandoli G, Von EO, Ghosh JK, Ritz B (2016) Synergistic effects of air pollution and psychosocial stressors on adolescent lung function. J Allergy Clin Immunol 138, 918-920.

[139] Hicken MT, Dvonch JT, Schulz AJ, Mentz G, Max P (2014) Fine particulate matter air pollution and blood pressure: the modifying role of psychosocial stress. Environ Res 133, 195-203.

[140] Hicken MT, Adar SD, Diez Roux AV, O'Neill MS, Magzamen S, Auchincloss AH, Kaufman JD (2013) Do psychosocial stress and social disadvantage modify the association between air pollution and blood pressure?: The multi-ethnic study of atherosclerosis. Am J Epidemiol 178, 1550-1562.

[141] Bolton JL, Huff NC, Smith SH, Mason SN, Foster WM, Auten RL, Bilbo SD (2013) Maternal stress and effects of prenatal air pollution on offspring mental health outcomes in mice. Environ Health Perspect 121, 1075-1082.

[142] Ailshire J, Karraker A, Clarke P (2017) Neighborhood social stressors, fine particulate matter air pollution, and cognitive function among older U.S. adults. Soc Sci Med 172, 56-63.

[143] Glass TA, Bandeen-Roche K, Mcatee M, Bolla K, Todd AC, Schwartz BS (2009) Neighborhood psychosocial hazards and the association of cumulative lead dose with cognitive function in older adults. Am J Epidemiol 169, 683-692.
[144] Peters JL, Weisskopf MG, Spiro A, III, Schwartz J, Sparrow D, Nie H, Hu H, Wright RO, Wright RJ (2010) Interaction of stress, lead burden, and age on cognition in older men: the VA Normative Aging Study. Environ Health Perspect 118, 505-510.

[145] Virgolini MB, Chen K, Weston DD, Bauter MR, CorySlechta DA (2005) Interactions of chronic lead exposure and intermittent stress: consequences for brain catecholamine systems and associated behaviors and HPA axis function. Toxicol Sci 87, 469-482.

[146] Virgolini MB, Bauter MR, Weston DD, Cory-Slechta DA (2006) Permanent alterations in stress responsivity in female offspring subjected to combined maternal lead exposure and/or stress. Neurotoxicology 27, 11-21.

[147] Cory-Slechta DA, Virgolini MB, Thiruchelvam M, Weston DD, Bauter MR (2004) Maternal stress modulates the effects of developmental lead exposure. Environ Health Perspect 112, 717-730.

[148] Tzivian L, Jokisch M, Winkler A, Weimar C, Hennig F, Sugiri D, Soppa VJ, Dragano N, Erbel R, Jockel KH, Moebus S, Hoffmann B (2017) Associations of long-term exposure to air pollution and road traffic noise with cognitive function-an analysis of effect measure modification. Environ Int 103, 30-38.

[149] Mehta AJ, Kubzansky LD, Coull BA, Kloog I, Koutrakis P, Sparrow D, Spiro A, III, Vokonas P, Schwartz J (2015) Associations between air pollution and perceived stress: the Veterans Administration Normative Aging Study. Environ Health 14, 10.

[150] Charmandari E, Tsigos C, Chrousos G (2005) Endocrinology of the stress response. Annu Rev Physiol 67, 259-284.

[151] Thomas J, Guenette J, Thomson EM (2018) Stress axis variability is associated with differential ozoneinduced lung inflammatory signaling and injury biomarker response. Environ Res 167, 751-758.

[152] Bale TL (2014) Lifetime stress experience: transgenerational epigenetics and germ cell programming. Dialogues Clin Neurosci 16, 297-305.

[153] Niu Y, Chen R, Xia Y, Cai J, Ying Z, Lin Z, Liu C, Chen C, Peng L, Zhao Z, Zhou W, Chen J, Wang D, Huo J, Wang X, Fu Q, Kan H (2018) Fine particulate matter constituents and stress hormones in the hypothalamuspituitary-adrenal axis. Environ Int 119, 186-192.

[154] Beishuizen A, Thijs LG (2003) Endotoxin and the hypothalamo-pituitary-adrenal (HPA) axis. $J$ Endotoxin $\operatorname{Res}$ 9, 3-24. 